\title{
PENGARUH KOMUNIKASI ORANG TUA DAN MOTIVASI BELAJAR SISWA TERHADAP PRESTASI BELAJAR IPS (SISWA KELAS VIII SMP NEGERI 2 SAKRA BARAT KABUPATEN LOMBOK TIMUR NTB)
}

\author{
Muh. Zainur Rahman ${ }^{1}$, Nurin Rochayati ${ }^{2}$ \\ ${ }^{1,2}$ Dosen Program Studi Pendidikan Geografi FKIP, Universitas Muhammadiyah Mataram \\ Email: nurin.geo99@yahoo.com
}

\begin{abstract}
ABSTRAK
Pengaruh Komunikasi Orang Tua dan Motivasi Belajar Siswa Terhadap Prestasi Belajar IPS (Kelas VIII SMP Negeri 2 Sakra Barat Lombok Timur NTB) Fokus penelitian ini (1). Apakah pengaruh komunikasi orang tua dengan siswa terhadap prestasi belajar mata pelajaran IPS, (2). Apakah motivasi belajar berpengaruh terhadap prestasi belajar pada mata pelajaran IPS, ( 3). Apakah ada pengaruh komunikasi orang tua dan motivasi belajar terhadap prestasi belajar siswa pada mata pelajaran IPS. Tujuan penelitian ini : (1) Untuk mengetahui besarnya pengaruh komunikasi orang tua terhadap prestasi belajar IPS,(2) Untuk mengetahui besarnya pengaruh motivasi belajar siswa pada mata pelajaran IPS, (3) Untuk mengetahui pengaruh komunikasi orang tua dan motivasi belajar terhadap prestasi belajar mata pelajaran IPS. Penelitian ini menggunakan teknik analisis statistik deskriptif dan analisis statistik inferensial. Hasil penelitian : Komunikasi Orang Tua dan Motivasi Belajar Siswa secara bersama-sama berpengaruh nyata terhadap Prestasi Belajar IPS Siswa SMP Negeri 2 Sakra Barat Lombok Timur NTB di tunjukkan oleh hasil uji F pada tingkat kesalahan 5\%, diperoleh nilai $F_{\text {hitung }}$ sebesar 133,167 dengan probabilitas kesalahan sebesar $0,00 \%$. Besarnya pengaruh dilihat dari nilai $\mathrm{R}$ Square (koefisien determinasi) sebesar 0,878, yang memberikan arti bahwa Komunikasi Orang Tua dan Motivasi Belajar Siswa dapat menjelaskan Prestasi Belajar IPS Siswa SMP Negeri 2 Sakra Barat Lombok Timur NTB sebesar $87,80 \%$, sedangkan sisanya sebesar $12,20 \%$ dijelaskan oleh variabel lain
\end{abstract}

Kata Kunci : Komunikasi Orang Tua, Motivasi Belajar, Prestasi Belajar, Siswa Kelas VIII SMP Negeri 2 Sakra Barat

\section{PENDAHULUAN}

Komunikasi keluarga terhadap anak dapat memberikan motivasi belajar sehingga dapat meningkatkan prestasi belajar siswa tidak terlepas dari peran guru sebagai pihak yang mengajar dan membimbing siswa. Hal ini mengimplikasikan bahwa Proses Belajar Mengajar (PBM) merupakan suatu proses interaksi antara guru dan siswa yang didasari oleh hubungan yang bersifat mendidik dalam rangka pencapaian tujuan. Dalam proses belajar mengajar, peran orang tua sangat dibutuhkan untuk memberikan motivasi yang merupakan salah satu faktor yang diduga besar pengaruhnya terhadap hasil belajar. Siswa yang motivasinya tinggi diduga akan memperoleh hasil belajar yang baik. Pentingnya motivasi belajar siswa terbentuk antara lain agar terjadi perubahan belajar ke arah yang lebih positif. Siswa yang termotivasi dengan baik dalam belajar melakukan kegiatan lebih banyak dan lebih cepat, dibandingkan dengan siswa yang kurang termotivasi dalam belajar. Prestasi yang diraih akan lebih baik apabila mempunyai motivasi yang tinggi."

Begitu pula halnya bila kita lihat dalam proses belajar mengajar IPS. Siswa yang sering melakukan komunikasi dengan orang tua akan memiliki motivasi yang tinggi dalam mempelajari IPS. Ini akan membantu untuk melakukan kegiatan lebih cepat dibandingkan dengan siswa yang kurang termotivasi dalam mempelajari IPS. Seringnya orang tua melakukan komunikasi dengan anak akan membuat anak tersebut memiliki motivasi yang tinggi dalam mempelajari IPS maka prestasi yang diraih juga akan lebih baik. Berdasarkan uraian tersebut menjadi landasan bagi penulis untuk mengadakan penelitian tentang Peran Komunikasi Orang Tua, Motivasi Belajar Siswa Dan Prestasi Belajar IPS. 


\section{Konsep Dasar Komunikasi \\ A. Pengertian Komunikasi}

Komunikasi adalah suatu proses pembentukan, penyampaian, penerimaan dan pengelolaan pesan yang terjadi dalam diri seseorang atau dua orang atau lebih dengan tujuan tertentu. Paradigma tersebut mengindikasikan bahwa komunikasi melibatkan lima unsur sebagai jawaban dari pertanyaan yang diajukan itu, yakni; (1) komunikator (who); (2) pesan dan massage (says what); (3) saluran atau channel (in which channel); (4) Komunikan (to Whom), dan (5) pengaruh atau effect (Whit What effect). Secara esensial komunikasi adalah proses penyampaian pesan oleh seseorang (Komunikator) yang dapat memberi pengaruh terhadap orang yang terlibat di dalamnya atau penerima pesan (Komunikan), baik menggunakan bahasa verbal maupun nonverbal.

$\begin{array}{lll}\text { 1. Komponen dalam } & \text { Proses } \\ \text { Komunikasi } & & \\ \text { Komponen-komponen } & \text { tersebut }\end{array}$ secara singkat dapat dijelaskan sebagai berikut:
a. Sumber (Komunikator)
b. Pesan (message)
c. Saluran (Channel)
d. Penerima pesan (Komunikan)
e. Efek atau hasil

2. Komunikasi orang tua dan anak Komunikasi orang tua sebagai pendidik meliputi: (1) kesadaran akan kemajuan pendidikan anak, (2) keterlibatan dalam kegiatan belajar anak di sekolah maupun di rumah, (3) keterlibatan dalam menciptakan kondisi belajar yang baik, (4) penyediaan fasilitas belajar, dan (5) bimbingan serta dorongan untuk lebih menggiatkan anak belajar.

\section{Pembelajaran di kelas}

Prestasi belajar adalah dua buah kata yang mempunyai arti tersendiri. Prestasi dapat diartikan sebagai hasil yang dicapai setelah suatu kegiatan belajar selesai dilaksanakan. Adinegara dalam Ensiklopedia umum (1954: 298) menjelaskan bahwa prestasi adalah segala pekerjaan yang berhasil. Skinner (1999: 9), berpendapat belajar adalah suatu perilaku, pada saat orang belajar, maka responnya menjadi lebih baik. Sedangkan Witherington (1982: 54) menyatakan, bahwa belajar itu kompleks dan harus melalui bermacam-macam kegiatan yaitu: (1) Anak harus berbuat melakukan apa yang di pelajarinya; (2) mendengarkan, mengingat, membaca buku; (3) berpikir, menganalisis dan menggunakan pengalaman masa lampau. Dari paparan di atas, dapatkah disimpulkan bahwa prestasi belajar adalah hasil belajar yang dicapai oleh seseorang dengan melakukan kegiatan belajar yang dapat diukur langsung melalui test atau melihat hasil test yang didapatkan dalam buku laporan pendidikan.

\section{Komunikasi yang diharapkan terjadi antara orang tua dan anak \\ Pendapat Devito (1997), bahwa} komunikasi antarpribadi merupakan pengiriman pesan dari seseorang dan diterima oleh orang lain yang efek dan umpan balik yang langsung. Komunikasi antar pribadi dari sudut pandang humanistik yang dikemukakan oleh Devito (1997) mempunyai ciri-ciri:

a. Keterbukaan (openness), yang mengacu pada tiga aspek komunikasi

b. Empati (empathy), yaitu kemampuan orang tua memposisikan dirinya

c. Sikap mendukung (supportiveness), Artinya keterbukaan dan empati dapat terlaksana jika terjadi dalam suasana yang mendukung (kondusif.

d. Sikap positif (positiveness), artinya dalam berkomunikasi orang tua harus memiliki sikap positif terhadap anaknya.

e. Kesetaraan (equality) artinya komunikasi akan lebih efektif apabila suasananya setara.

B. Pengertian Motivasi Belajar Siswa Motivasi dapat diartikan sebagai kekuatan (energi) seseorang yang dapat menimbulkan tingkat persistensi dan antusiasmenya dalam melaksanakan suatu kegiatan, baik yang bersumber dari dalam diri individu itu sendiri (motivasi intrinsik) maupun dari luar individu (motivasi ekstrinsik). Peranan Motivasi dalam Belajar adalah dorongan yang menyebabkan terjadinya suatu perbuatan atau tindakan. Perbuatan belajar pada siswa terjadi karena adanya motivasi untuk melakukan perbuatan belajar. Sardiman (1988 : 84) mengemukakan ada tiga fungsi motivasi, yaitu : 
a. Mendorong manusia untuk berbuat. Motivasi dalam hal ini merupakan motor penggerak dari setiap kegiatan yang akan dikerjakan.

b. Menuntun arah perbuatan, yakni ke arah tujuan yang hendak dicapai, dengan demikian motivasi dapat memberi arah, dan kegiatan yang harus dikerjakan sesuai dengan rumusan tujuannya.

c. Menyeleksi perbuatan, yakni menentukan perbuatan-perbuatan apa yang harus dikerjakan yang serasi guna mencapai tujuan, dengan menyisihkan perbuatanperbuatan yang tidak bermanfaat bagi tujuan tersebut.

Dalam rangka mengupayakan agar motivasi belajar siswa tinggi, seorang guru menurut Winkel (1991) hendaknya selalu memperhatikan hal-hal sebagai berikut:

(1) Seorang guru hendaknya mampu mengoptimalisasikan penerapan prinsip belajar.

(2) Guru hendaknya mampu mengoptimalisasikan unsur-unsur dinamis dalam pembelajaran.

(3) Guru mengoptimalisasikan pemanfataan pengalaman dan kemampuan siswa.

\section{Prestasi Belajar IPS}

IImu pengetahuan sosial (IPS) merupakan salah satu mata pelajaran yang diberikan mulai dari SD sampai SMP / MTS. IPS mengkaji seperangkat peristiwa, fakta, konsep, dan generalisasi yang berkaitan dengan isu sosial. Pada jenjang SMP / MTs mata pelajaran IPS memuat materi Geografi, Sejarah, Sosiologi, dan Ekonomi. Mata pelajaran IPS bertujuan agar peserta didik memiliki kemampuan sebagai berikut :

a. Mengenal konsep-konsep yang berkaitan dengan kehidupan masyarakat dan lingkungannya. b. Memiliki kemampuan dasar untuk berpikir logis dan kritis, rasa ingin tahu, inkuiri, memecahkan masalah, dan ketrampilan dalam kehidupan sosial.

c. Memiliki komitmen dan kesadaran terhadap nilai-nilai sosial dan kemanusiaan.

d. Memiliki kemampuan berkomunikasi, bekerjasama dan berkompetisi dalam masyarakat majemuk, tingkat lokal, nasional, dan global.

Ruang lingkup mata pelajaran IPS meliputi asfek-asfek sebagai berikut :

a. Manusia, tempat, dan lingkungan.

b. Waktu, keberlanjutan, dan perubahan.

c. Sistem sosial dan budaya

d. Perilaku ekonomi dan kesejahtraan.

\section{Penilaian Prestasi Belajar}

Tujuan penilaian adalah untuk mengetahui dan mengumpulkan informasi terhadap perkembangan dan kemajuan, dalam rangka mencapai tujuan yang ditetapkan dalam kurikulum. Fungsi penilaian dapat dikatakan sebagai suatu evaluasi yang dilakukan sekolah mempunyai tiga fungsi pokok yang penting, yaitu: (1) untuk mengetahui perkembangan dan kemajuan, dalam rangka waktu tertentu, (2) untuk mengetahui sampai di mana perbaikan suatu metode yang digunakan guru dalam mendidik dan mengajar, dan (3) dengan mengetahui kesalahan dan kekurangan yang terdapat dalam evaluasi selanjutnya dapat diusahakan perbaikan, Purwanto (2000 : 10). Teknik dan alat penilaian yang sering digunakan kepala sekolah adalah: (1) teknik tes, terdiri dari tes tertulis, yaitu: tes objektif dan tes uraian, tes lisan, dan tes perbuatan, (2) teknik non tes yang dilaksanakan melalui observasi maupun pengamatan (Depdiknas, $2000: 4$ ). 


\section{Kerangka Berpikir}

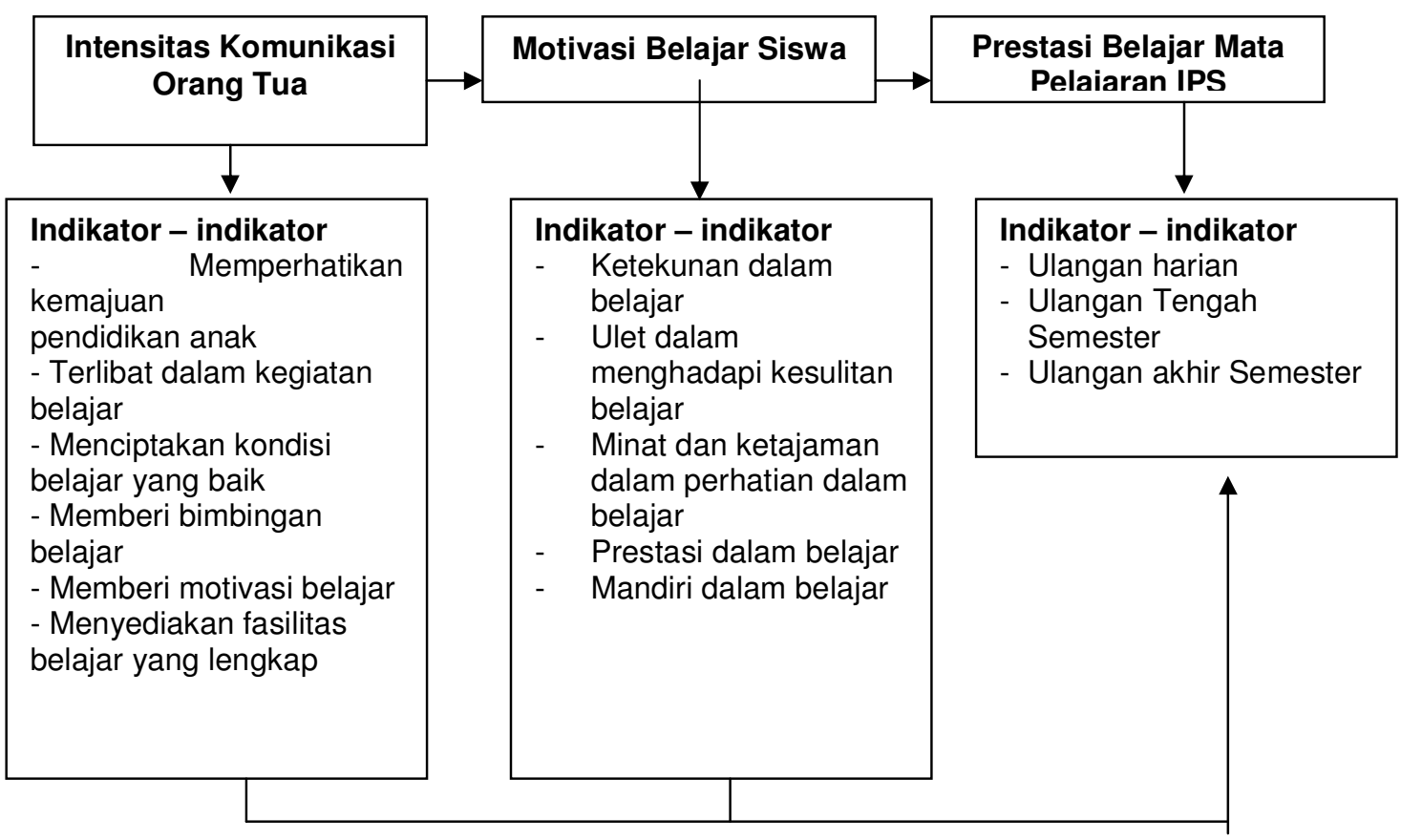

Bagan 1. Model Kerangka Pemikiran

\section{Hipotesis}

Mengacu pada tinjauan pustaka dan kerangka pemikiran yang telah dikemukakan, maka diajukan hipotesis penelitian sebagai berikut:

1. Ada pengaruh yang signifikan "Intensitas Komunikasi Orang Tua Terhadap Prestasi Belajar IPS.

2. Ada pengaruh yang signifikan "Motivasi Belajar Terhadap Prestasi Belajar IPS.

3. Ada pengaruh yang signifikan " Intensitas Komunikasi Orang Tua dan Motivasi Belajar siswa Terhadap Prestasi Belajar IPS.

III. METODE PENELITIAN

A. Rancangan Penelitian

Desain penelitiannya dalam bentuk skema sebagai berikut:

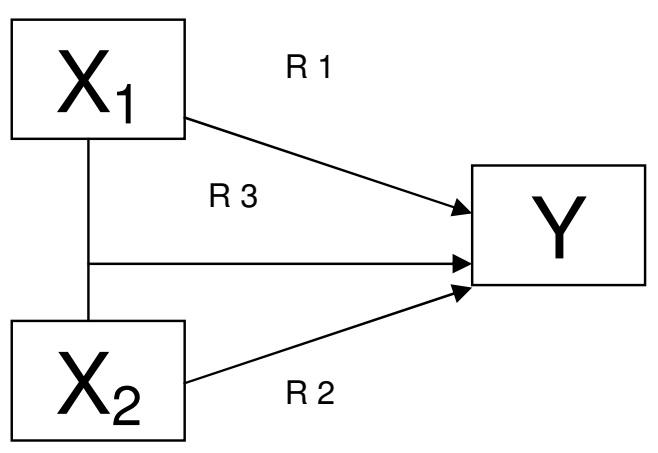

\footnotetext{
Bagan 2. Desain Penelitian

Keterangan:

$\mathrm{X}_{1}=$ Intensitas Komunikasi Orang Tua Siswa Kelas VIII SMP Negeri 2 Sakra Barat Lombok Timur NTB".

$\mathrm{X}_{2}=$ Motivasi Belajar IPS Siswa Kelas VIII SMP Negeri 2 Sakra Barat Lombok Timur NTB
} 
$\mathrm{Y}=$ Prestasi Belajar IPS Siswa Kelas VIII SMP Negeri 2 Sakra Barat Lombok Timur NTB

\section{B. Variabel Penelitian}

Penelitian ini mengkaji tiga variabel yaitu " intensitas komunikasi orang tua dan motivasi belajar siswa" sebagai variabel bebas (independen variabel) yang diberi simbol $\left(X_{1}\right.$ dan $\left.X_{2}\right)$ dan " prestasi belajar IPS " sebagai variabel terikat (dependen variabel) yang diberi simbol $(\mathrm{Y})$.

\section{Analisis data}

Untuk menganalisis data dalam penelitian ini menggunakan teknikanalisis statistik deskriptif dan analisis statistik inferensial.

\section{HASIL PENELITIAN DAN PEMBAHASAN}

\section{A. Analisis Pengaruh Orang Tua dan Motivasi Belajar Siswa terhadap Prestasi Belajar IPS \\ Untuk menganalisis Pengaruh}

Komunikasi Orang Tua dan Motivasi Belajar Siswa terhadap Prestasi Belajar IPS, peneliti menggunakan analisis Regresi Linier Berganda, lengkap dengan pengkajian dan penentuan ada tidaknya hubungan antara masing-masing variabel independen dengan variabel dependen.

Dalam penelitian ini ditetapkan dua variabel independen yaitu Komunikasi Orang Tua (X1) dan Variabel Motivasi Belajar Siswa (X2), sedangkan Variabel Prestasi Belajar IPS sebagai variabel dependen (Y).

Berdasarkan model yang telah disyaratkan dalam metode Ordinari Least Square (OLS) dari hasil perhitungan statistik dengan menggunakan Program SPSS, maka dihasilkan data output sebagaimana tercantum dalam Tabel 1 dibawah ini.

Tabel 1 : Hasil Regresi Berganda pengaruh Komunikasi Orang Tua dan Motivasi Belajar Siswa terhadap Prestasi Belajar IPS

\begin{tabular}{lcrrr}
\hline Variabel & $\begin{array}{c}\text { Parame } \\
\text { ter }\end{array}$ & Koeffisien & t-value & Probability \\
\hline Konstanta & bo & 16,495 & 3,858 & 0,000 \\
Komunikasi Orang Tua (X1) & b1 & 0,837 & 4,376 & 0,000 \\
Motivasi Belajar Siswa (X2) & b2 & 0,573 & 8,675 & 0,000 \\
\hline R & $=0,937$ & & & \\
R-square & $=0,878$ & & & \\
F-value & $=133,167(p=0,000)$ & & & \\
Sumber : Data diolah, tahun 2014.
\end{tabular}

Berdasarkan hasil analisis regresi berganda pada Tabel 1, maka dapat dibuat persamaan sebagai berikut:

$y=b o+b 1 \times 1+b 2 \times 2$

$y=19,495+0,837 X_{1}+0,573 X_{2}$

1. Analisis Simultan

Secara simultan (bersama-sama) pengaruh variabel independen terhadap variabel dependen dapat dilihat dari nilai $R$ Square (koefisien determinasi) sebesar 0,878 , yang memberikan arti bahwa variable Komunikasi Orang Tua dan variable Motivasi Belajar Siswa dapat menjelaskan Prestasi Belajar IPS Siswa SMP Negeri 2 Sakra Barat Lombok Timur NTB sebesar $87,80 \%$, sedangkan sisanya sebesar 12,20\% dijelaskan oleh variabel lain, selain Komunikasi Orang Tua dan Motivasi Belajar Siswa.

Hasil uji $F$ pada tingkat kesalahan $5 \%$, diperoleh nilai $F_{\text {hitung }}$ sebesar 133,167 dengan $F_{\text {tabel }}$ sebesar 2,84 maka menolak hopotesis nol $\left(F_{\text {hitung }}>F_{\text {tabel }}\right)$. Signifikansi dari uji statistik $F$ ini juga ditunjukkan oleh besarnya probabilitas kesalahan sebesar $0,00 \%$. Hal ini menunjukkan bahwa kemampuan variabel Komunikasi Orang Tua dan Motivasi Belajar Siswa dalam menjelaskan Prestasi Belajar IPS Siswa SMP Negeri 2 Sakra Barat Lombok Timur NTB adalah nyata/signifikan. 


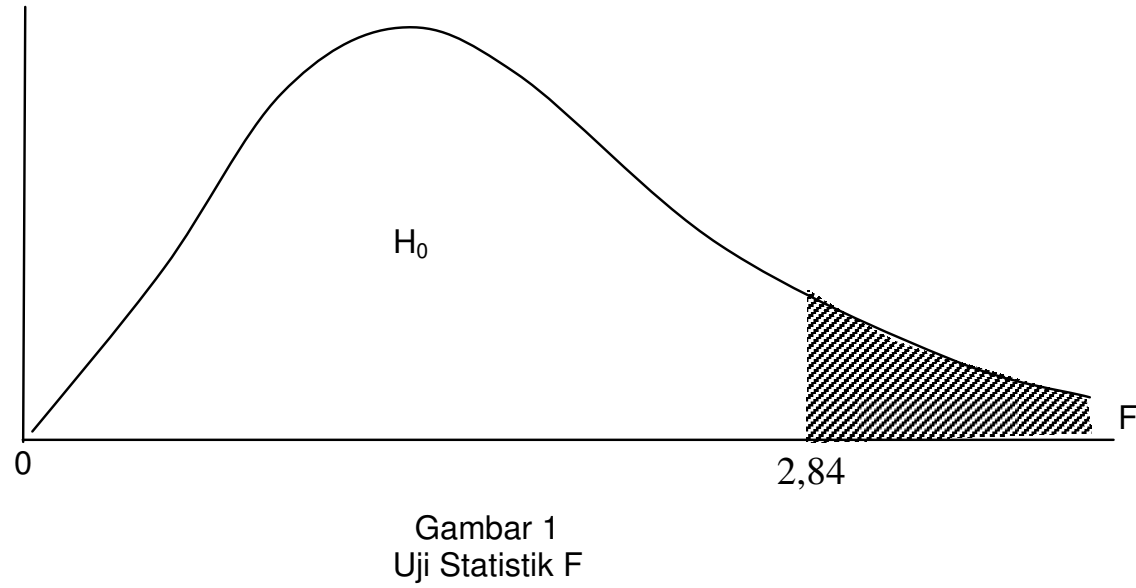

Berdasarkan analisis tersebut, Komunikasi Orang Tua dan Motivasi Belajar Siswa secara bersama-sama sangat efektif untuk meningkatkan Prestasi Belajar IPS, dimana kedua variabel ini berperan sebesar $87,80 \%$ menentukan Prestasi Belajar IPS. Pengaruh yang sangat besar oleh kedua variabel tersebut dalam meningkatkan Prestasi Belajar IPS, memberikan informasi kepada peneliti, bahwa agar supaya Prestasi Belajar IPS Siswa SMP Negeri 2 Sakra Barat Lombok Timur NTB mengalami peningkatan, maka perlu adanya komunikasi yang baik yang berasal dari orang tua, maupun motivasi belajar dari siswa yang bersangkutan.

\section{Uji Parsial}

Untuk melihat sejauhmana peran masing-masing variabel independen yaitu komunikasi orang tua dan motivasi belajar siswa berpengaruh terhadap variabel dependen yaitu Prestasi Belajar IPS Siswa SMP Negeri 2 Sakra Barat Lombok Timur NTB, maka selanjutnya peneliti perlu melakukan uji secara parsial terhadap kedua variabel independen tersebut.

Nilai konstanta pada persamaan regresi linier berganda sebesar 16,495 sebagai variabel eksogeneous, memberikan arti bahwa Prestasi Belajar IPS (Y) adalah 16,495 satuan pada saat besarnya Komunikasi Orang Tua (X1) dan Motivasi Belajar Siswa (X2) sama dengan 0 (nol) atau pada saat tidak ada Komunikasi Orang Tua dan Motivasi Belajar Siswa.

\section{B. Uji Parsial Pengaruh Variabel Komunikasi Orang Tua terhadap Prestasi Belajar IPS \\ Variabel Komunikasi Orang Tua (X1)} mempunyai koefisien regresi sebesar 0,837, hal ini berarti jika Komunikasi Orang Tua mengalami kenaikan sebesar satu satuan maka Prestasi Belajar IPS Siswa SMP Negeri 2 Sakra Barat Lombok Timur NTB (Y) akan mengalami kenaikan sebesar 0,837 satuan, cateris paribus.

Hasil uji statistik $t$ pada tingkat kesalahan $5 \%$ menunjukkan bahwa variabel Komunikasi Orang Tua $\left(X_{1}\right)$ mempunyai nilai $t$ hitung sebesar 4,376 dengan probabilitas kesalahan sebesar $0,0 \%$, yang berarti variabel Komunikasi Orang Tua mempunyai pengaruh nyata/signifikan terhadap Prestasi Belajar IPS Siswa Kelas VIII SMP Negeri 2 Sakra Barat Lombok Timur NTB.

Hasil analisis tersebut memberikan informasi bahwa peran komunikasi orang tua dengan anaknya sangat penting bagi perkembangan prestasi anaknya dalam belajar IPS. Suasana komunikasi orang tua di rumah mempunyai peranan penting dalam menentukan kehidupan anak di sekolah. Orang tua yang kurang memperhatikan kemajuan pendidikan anaknya dapat menyebabkan anaknya kurang berhasil dalam belajarnya. Perhatian yang diberikan harus disesuaikan dengan kebutuhan anak, dimana keluarga merupakan lingkungan pendidikan yang utama bagi para siswa, 
sebab pada lingkungan keluarga inilah seorang siswa pertama-tama memperoleh pengalaman hidupnya, yang menjadi dasar bagi perkembangan hidup. dan siswa lebih banyak waktu di rumah dibandingkan dengan disekolah, sehingga lingkungan keluarga banyak dihubungkan dengan prestasi belajar anak.

Karena itu, yang bertanggung jawab sepenuhnya terhadap pendidikan seorang anak bukan hanya terletak pada guru, namun peran orang tua lebih menentukan, di samping lingkungan sekolah, dan lingkungan masyarakat. Orang tua menjadi salah satu kunci keberhasilan anak dalam belajar, sehingga orang tua perlu menciptakan komunikasi yang intens dengan anaknya terhadap proses belajar anaknya. Orang tua harus menjadikan rumah sebagai wadah untuk berkomunikasi secara intens dengan anaknya yang berhubungan dengan kegiatan belajar anak di rumah dan di luar rumah serta pemenuhan kebutuhan belajar anak. Orang tua dituntut selalu mengkomunikasikan kebutuhan pendidikan anaknya, karena anak membutuhkan komunikasi dalam bentuk perhatian dan penghargaan sebab komunikasi seperti itu dapat memberi motivasi dan memperlancar proses belajar anak. Apabila dihubungkan antara kehidupan anak di rumah dengan orang tua, maka orang tua harus menciptakan rumah itu sebagai "learning environment", mengajarkan nilainilai kebaikan moral, etis, dan sebagainya. Orang tua dituntut untuk dapat bersikap seperti guru. Tahu masalah, dan tugas anaknya di sekolah. la juga harus pandai mengevaluasi perkembangan anaknya, lebih berpengaruh dari guru dan sebagainya.

Komunikasi orang tua dengan anaknya dalam kegiatan belajar IPS sangat diperlukan, sebab komunikasi seperti itu dapat meningkatkan kualitas belajar anak. Komunikasi yang harmonis antara orang tua dengan anaknya adalah komunikasi yang penuh pengertian dan kasih sayang, disertai bimbingan dan bila perlu hukuman-hukuman untuk menyukseskan belajar anak sendiri. Orang tua harus dapat menciptakan suasana rumah menjadi tenang dan tentram sehingga anaknya betah dan bergairah untuk belajar. Di samping itu, yang tidak kalah pentingnya adalah bagaimana orang tua mengkomunikasikan kebutuhan fasilitas belajar anaknya. komunikasi orang tua sebagai pendidik meliputi: kesadaran akan kemajuan pendidikan anak, keterlibatan dalam kegiatan belajar anak di sekolah maupun di rumah, keterlibatan dalam menciptakan kondisi belajar yang baik, penyediaan fasilitas belajar, dan bimbingan serta dorongan untuk lebih menggiatkan anak belajar IPS.

\section{Uji Parsial Pengaruh Motivasi Belajar Siswa terhadap Prestasi Belajar IPS}

Variabel Motivasi Belajar Siswa (X2) mempunyai koefisien regresi sebesar 0,573, hal ini berarti jika Motivasi Belajar Siswa mengalami kenaikan sebesar satu satuan maka Prestasi Belajar IPS Siswa SMP Negeri 2 Sakra Barat Lombok Timur NTB (Y) akan mengalami kenaikan sebesar 0,573 satuan, cateris paribus.

Hasil uji statistik t pada tingkat kesalahan $5 \%$ menunjukkan bahwa variabel Motivasi Belajar Siswa (X2) mempunyai nilai t hitung sebesar 8,675, dengan probabilitas kesalahan sebesar 0,0\%, yang berarti variabel Motivasi Belajar Siswa mempunyai pengaruh nyata/signifikan terhadap Prestasi Belajar IPS Siswa SMP Negeri 2 Sakra Barat Lombok Timur NTB.

Motivasi dapat memberikan kekuatan (energi) yang dapat meningkatkan antusias siswa dalam belajar, baik yang bersumber dari dalam diri individu itu sendiri (motivasi intrinsik) maupun dari luar individu (motivasi ekstrinsik). Seberapa kuat motivasi yang dimiliki siswa akan banyak menentukan terhadap kualitas belajarnya, dalam upaya pencapaian prestasi belajar IPS seorang siswa.

Motivasi mempunyai fungsi yang penting dalam belajar, karena motivasi akan menentukan intensitas usaha belajar yang dilakukan siswa. para siswa yang memiliki motivasi tinggi, belajarnya lebih baik dibandingkan dengan siswa yang motivasi belajarnya rendah. Hal ini dapat dipahami, karena siswa yang memiliki motivasi belajar tinggi akan tekun dalam belajar dan terus belajar secara kontinyu tanpa mengenal putus asa serta dapat mengesampingkan halhal yang dapat mengganggu kegiatan belajar yang dilakukannya. 
Aspek motivasi dalam keseluruhan proses belajar mengajar sangat penting, karena motivasi dapat mendorong siswa untuk melakukan aktivitas-aktivitas tertentu yang berhubungan dengan kegiatan belajar. Motivasi dapat memberikan semangat kepada siswa dalam kegiatan-kegiatan belajarnya dan memberi petunjuk atas perbuatan yang dilakukannya. sehingga siswa yang bersangkutan dapat mencapai hasil belajar yang optimal.

Siswa dalam belajar hendaknya merasakan adanya kebutuhan psikologis yang normatif. Siswa yang termotivasi dalam belajarnya dapat dilihat dari karakteristik tingkah laku yang menyangkut minat, ketajaman, perhatian, konsentrasi, dan ketekunan. Siswa yang memiliki motivasi rendah dalam belajarnya menampakkan keengganan, cepat bosan, dan berusaha menghindar dari kegiatan belajar. sehingga motivasi menentukan tingkat berrhasil tidaknya kegiatan belajar siswa. Sehingga wajar kalau motivasi siswa menjadi salah satu faktor yang menentukan prestasi belajar IPS seorang siswa.

Mengingat demikian pentingnya peranan motivasi bagi siswa dalam belajar, maka segenap stake holder dibidang pendidikan diharapkan dapat membangkitkan dan meningkatkan motivasi belajar siswa, agar siswa dapat mencapai hasil belajar yang optimal, karena pada kenyataannya tidak semua siswa memiliki motivasi belajar yang tinggi dalam belajar.

\section{KESIMPULAN DAN SARAN}

Sesuai dengan latar belakang dan permasalahan yang ada, maka hasil penelitian diatas dapat disimpulkan bahwa:

1. Komunikasi Orang Tua dan Motivasi Belajara Siswa secara bersama-sama berpengaruh nyata terhadap Prestasi Belajar IPS Siswa SMP Negeri 2 Sakra Barat Lombok Timur NTB di tunjukkan oleh hasil uji $\mathrm{F}$ pada tingkat kesalahan $5 \%$, diperoleh nilai $F_{\text {hitung sebesar }}$ 133,167 dengan probabilitas kesalahan sebesar 0,00\%. Besarnya pengaruh dilihat dari nilai $R$ Square (koefisien determinasi) sebesar 0,878, yang memberikan arti bahwa Komunikasi Orang Tua dan Motivasi Belajar Siswa dapat menjelaskan Prestasi Belajar IPS Siswa SMP Negeri 2 Sakra Barat Lombok Timur NTB sebesar $87,80 \%$, sedangkan sisanya sebesar 12,20\% dijelaskan oleh variabel lain;

2. Komunikasi Orang Tua berpengaruh nyata/signifikan terhadap Prestasi Belajar IPS Siswa SMP Negeri 2 Sakra Barat Lombok Timur NTB. Orang tua menjadi salah satu kunci keberhasilan anak dalam belajar, sehingga orang tua perlu menciptakan komunikasi yang intens dengan anaknya terhadap proses belajar anaknya. Orang tua harus menjadikan rumah sebagai wadah yang paling tepat bagi siswa yang berhubungan dengan kegiatan belajar; dan

3. Motivasi Belajar Siswa berpengaruh nyata/signifikan terhadap Prestasi Belajar IPS Siswa SMP Negeri 2 Sakra Barat Lombok Timur NTB. Motivasi baik yang berasal dari internal maupun eksternal dapat membuat seseorang siswa terdorong untuk selalu disiplin dalam belajar sehingga Prestasinya meningkat.

\section{DAFTAR PUSTAKA}

Ahmad, Talim dan Abdul Rahman 1992. Pengaruh Perhatian Orang Tua danJumlah Bersaudara terhadap Prestasi Belajar MatematikaSiswa Kelas 1 SMA Pembangunan Ujungpandang. Ujungpandang: Lembaga Penelitian IKIP Ujungpandang.

Anastasi, Anne. 1976. Psychological Testing. MacMillan PublishingCompany. Inc. New York. Andersch, E.G. et al. 1969. Communication in Everyday Use. Renehart Press.San Fransisco.

Ardana, Wayan. 1986. Dasar-dasar Kependidikan, Pengaruh Pendidikan luassekolahterhadap Pendidikan di Sekolah. Modul 4. IKIP Fakultas IlmuPendidikan. Malang.

Arikunto, Suharsimi. 1998. Prosedur Penelitian Suatu Pendekatan Praktek.PT. Rineka Cipta. Jakarta.

Arikunto, Suharsimi. 2000. Manajemen Penelitian. Jakarta : Rineka Cipta 
Dimyati dan Mudjiono. 1999. Belajar

dan Pembelajaran. Rineka

Cipta.Jakarta.rk

Sardiman A.M. 1992. Interaksi dan Motivasi Belajar Mengajar. Rajawali Pers.Jakarta.

Soehartono, Irawan. 1999. Metode Penelitian Sosial. Remaja Rosdakarya.Bandung.

Tiro, Muhammad Arif. 2000. Analisis Korelasi dan Regresi. Makassar University Press. Makassar.

Tirtaraharja, Umar dan La Sula. 2000. Pengantar Pendidikan. Reneka Cipta.Jakarta

Candiasa. 2007. Statistik Multivariat. Bahan Ajar. DIKSH . Undiksha Singaraja.

Depdikbud. 1997. Bahan Penataran Pengujian Pendidikan. Jakarta : Puslitbang Sisjian Balitbang Depdikbud.

Depdiknas. 2000. Penyusunan Butir Soal dan Instrumen Penilaian. Jakarta

-, 2007. Pendidikan dan Pelatihan Supervisi Akademik dalamPeningkatan Profesionalisme Guru. Jakarta

Dimyati \& Mudjiono. 1994. Belajar dan Pembelajaran. Jakarta : Proyek Pembinaan dan Peningkatan Mutu Kependidikan, Dirjen Dikti Depdikbud.

Djamarah, Syaiful Bahri. 2002. Psikologi Belajar. Jakarta : Rineka Cipta

Djalal, M.F. 1986. Penilaian Dalam Pengajaran Bahasa Asing. Malang: P3TIKIP Malang

Guilford. 1973. Pshycological Testing, Allyn Bacon. Inc

Hamalik, Oemar. 2000. Psikologi Belajar dan Manager. Bandung : Sinar BaruAlgessindo

Makmun, Abin Syamsudin. 1996. Psikologi Pendidikan. Bandung :Rosdakarya.

Moeliono, Anton, dkk. 2002. Kamus Besar Bahasa Indonesia. Edisi Ketiga.Jakarta : Balai Pustaka.

Nasution, Farid. 2001. Hubungan Metode Mengajar Dosen, KeterampilanBelajar, Sarana Belajar dan Lingkungan Belajar dengan Prestasi Beajar Mahasiswa. Jurnal IImu Pendidikan. Jilid 8. Nomor 1. 